\title{
The Causality Relationship between Nutrition and Economic Growth in Egypt
}

\section{Ahmed Abou El-Yazid El-Rasoul ${ }^{1}$ and Abd El-Atty Mohamed Mahmoud Ali ${ }^{2}$}

\author{
${ }^{1}$ Economics and Agribusiness Department, Faculty of Agriculture, Alexandria University, Alexandria, \\ Egypt. \\ ${ }^{2}$ Agricultural Economics Department, Faculty of Agriculture and Natural Resources, Aswan \\ University, Aswan, Egypt.
}

Received: 20 Dec. 2019 / Accepted 15 Mar. 2020 / Publication date: 30 Mar. 2020

\begin{abstract}
Food is a basic human right, and it affects health, productivity and income, and ultimately it is the basis for achieving sustainable economic growth. Egypt faces many challenges and future problems to achieve food security, as excessive dependence on food imports causes a problem in food security with high levels of malnutrition, reducing human capital development, aggravating the problem of poverty, low labor productivity, and the bottom line is low economic growth. The research aimed to study the causal relationship between nutrition intake and economic growth in Egypt. It was based on time series data for the period 1961-2017, calories per-capita daily intake, real food price index, real GDP per-capita and food production index. The research relied on standard methods for analyzing the time series in question. The most important search results can be summarized as follows:

- About $92.6 \%$ of the calories a person obtains daily from a plant source, and only about $7.4 \%$ of them are from animal and fish sources, which mean that the Egyptian citizen depends more on his food on the component of plant production than his dependence on animal and fish production, and this may be attributed Low per-capita income and widespread poverty, which explains the incidence of malnutrition diseases, especially anemia and stunting, among children.

- It was found that the independent variables included in the model are consistent with economic logic, as they collectively explain about $81.8 \%$ of the changes in the calories per-capita daily intake during the study period, and that the real GDP per-capita variable is the most influencing the calories per-capita daily intake in Egypt.

- Cointegration test indicate that there are two directions for the Cointegration between the study variables, and this result confirms the possibility of a balanced relationship in the long run.

- The results of Granger's causal test indicated that there is a one-way causal relationship that extends from both the real food price index, the real GDP per-capita to per-capita nutrition in Egypt, while there is a two-way causal relationship between food production and nutrition intake, that is, each of them causes the other one.

- The pulse response function showed that the independent variables have a noticeable effect on the interpretation of the shock response in calories intake, and it has been observed that the calories intake response to recent changes in real GDP per-capita is high. It was found that the condition of stability of the model used in the study was fulfilled by applying the test of the Roots of Characteristic Polynomial.
\end{abstract}

Keywords: Food Security, Economic Growth, Cointegration, Causality Relationship, Impulse Response.

\section{Introduction}

Food is a basic human right, and it affects health, productivity, income and ultimately economic growth. Food security not only carries great benefits for human health, but also serves as a basis for achieving sustainable economic growth. Although society can provide its nutritional needs (food security) either by producing it locally or by importing it from abroad, those interested in food security see that the greater the proportion of food produced locally, meaning that there is a high rate of selfsufficiency in food crops, the more This called for the continuity and non-threatening of food security, and that countries that cannot provide food to their people with their available resources become powerless to the pressures and challenges they face, which endangers their security, freedom, and

Corresponding Author: Ahmed Abou El-Yazid El-Rasoul, Economics and Agribusiness Department, Faculty of Agriculture, Alexandria University, Alexandria, Egypt.

E-mail: aabulyazid@alexu.edu.eg 
independence, and is diminished. Egypt faces many challenges to achieve food security, the most important of which are: encroachments on agricultural lands, future risks facing water resources, climate changes and their potential impacts, in addition to high prices of agricultural production requirements, lack of interest in food processing, and the absence of adequate attention in the agricultural marketing system, and an increase The price levels of food commodities at rates that exceed the increase in income, which indicates the volume of pressure that the consumer is exposed to, especially the low-income segment, as it is the first victim because of its inability to provide its basic material needs. Despite the increase in the food production index from 88.93 in 2000 to 125.14 in 2017, Egypt still faces serious future problems in agricultural production due to the limited water resource in particular, the increasing rate of population growth, low levels of technology, limited crop patterns and environmental restrictions.

\section{Problem Statement:}

The sustainability of economic growth depends on achieving food security by increasing domestic production and reducing dependence on food imports. Without a food security strategy, the country will bear a significant cost to maintain food security. The excessive dependence on food imports causes a problem in food security with high levels of chronic malnutrition, limiting the development of human capital, aggravating the problem of poverty, low labor productivity, low life expectancy and the bottom line of low economic growth.

\section{Objective:}

Applying econometric analysis to explore the long run causality relations across nutrition intake, economic growth, food prices and food production index in Egypt, and obtain the direction of causality between them.

\section{Data:}

The research based on time series data for the period 1961-2017, and the study variables were: calories per-capita daily intake $(\mathrm{Y})$, which represents the nutrition per-capita intake, the real food price index $(2010=100)\left(\mathrm{X}_{1}\right)$, real GDP Per-Capita $\left(\mathrm{X}_{2}\right)$, this variable reflects economic growth, Food Production Index $(2004-2006=100)\left(\mathrm{X}_{3}\right)$, compiled from the Food and Agriculture Organization of the United Nations (FAOSTAT) site and the World Bank websites.

\section{Methods:}

The research relied on the use of some standard methods for analyzing the time series under study to estimate the causal relationship between nutrition intake and economic growth in Egypt, during the period 1961-2017. According to Enders (1995), there are three basic standard steps that are followed for time series analysis:

(1 Unit root test for stability and the degree of integration, for each variable separately.

(2 Cointegration Test to identify the possibility of balance relationships between variables in the long run.

(3 Pairwise Granger Causality test to ensure the Feed-Back relationship between the study variables and determine the direction of causation between each of the two variables.

Also, the components of the Variance Decomposition were analyzed, the Impulse Response Function (IRF) was evaluated, and the stability of the model used was applied by applying the roots of characteristic polynomial test.

\section{Results and Discussion}

There are increasing concerns about poverty and malnutrition and how to achieve the sustainable growth, especially since the poverty rate in Egypt reached about 32.5\% at the end of 2019, besides this, there is an important question: Is there any link between economic growth and appropriate food consumption? It should be noted that the percentage of self-sufficiency is still low for some food commodities, as it averaged about $55.7 \%$ for wheat, $38.3 \%$ for beans, $67.3 \%$ for sugar, $74.8 \%$ for red meat, and $81 \%$ for both milk and fish. There is also a significant increase in the number of people 
suffering from malnutrition in Egypt, as their number increased from 3.7 in 2000 to 4.7 million in 2017, as shown in Figure No. 1. (Ministry of Agriculture, Food Balance Sheet Bulletin).

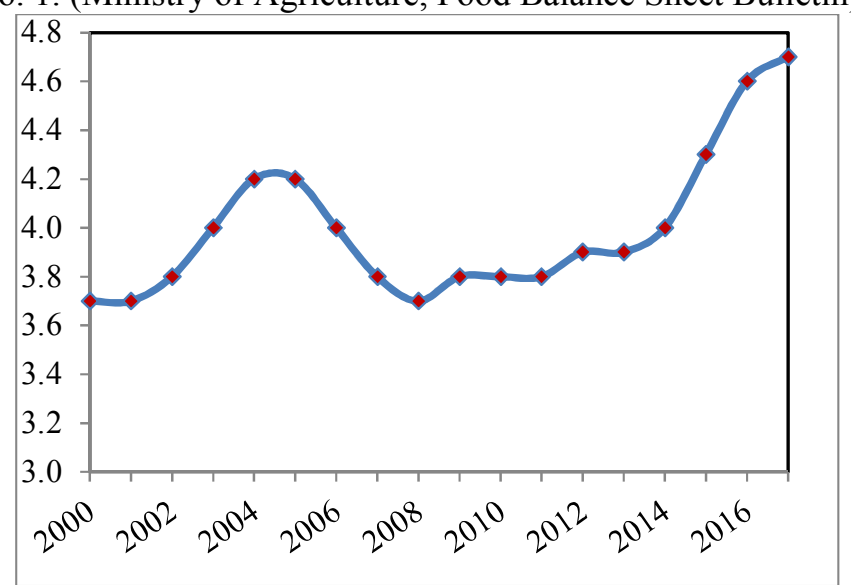

Fig. 1: Number of people suffering from malnutrition in Egypt during the period 2000-2017

This part analyzes the causal relationship between nutrition and economic growth in Egypt using the time series analysis methodology. The variables used are: Calories per-capita daily intake $(\mathrm{kcal} /$ capita/day $)(\mathrm{Y})$, Real Food Price Index $(2010=100)\left(\mathrm{X}_{1}\right)$, Real GDP per-capita $\left(\mathrm{X}_{2}\right)$, Food Production Index $(2004-2006=100)\left(X_{3}\right)$, during the period 1961-2017. A strong significant correlation was confirmed between the three independent variables and the dependent variable, as shown in Table No. 1.

Table 1: Correlation coefficients between independent and dependent variables

\begin{tabular}{ccccc}
\hline & & $\mathbf{X}_{\mathbf{1}}$ & $\mathbf{X}_{\mathbf{2}}$ & $\mathbf{X}_{\mathbf{3}}$ \\
\hline & Pearson Correlation & $-0.754^{* *}$ & $0.629^{* *}$ & $0.845^{* *}$ \\
$\mathbf{Y}$ & Sig. (2-tailed) & 0.000 & 0.000 & 0.000 \\
& $\mathrm{~N}$ & 57 & 57 & 57 \\
\hline
\end{tabular}

In Egypt, it should be noted that the calories per-capita daily intake (kcal/capita/day) tended to increase from 2076 in 1961 to 3308 in 2017, which is a high share compared to many countries in the world, but by distributing these calories according to its sources, it was found that about $92.6 \%$ of them came from a source It is vegetarian, and only about $7.4 \%$ of it are from animal and fish sources as an average of the study period, Figure No. (2).

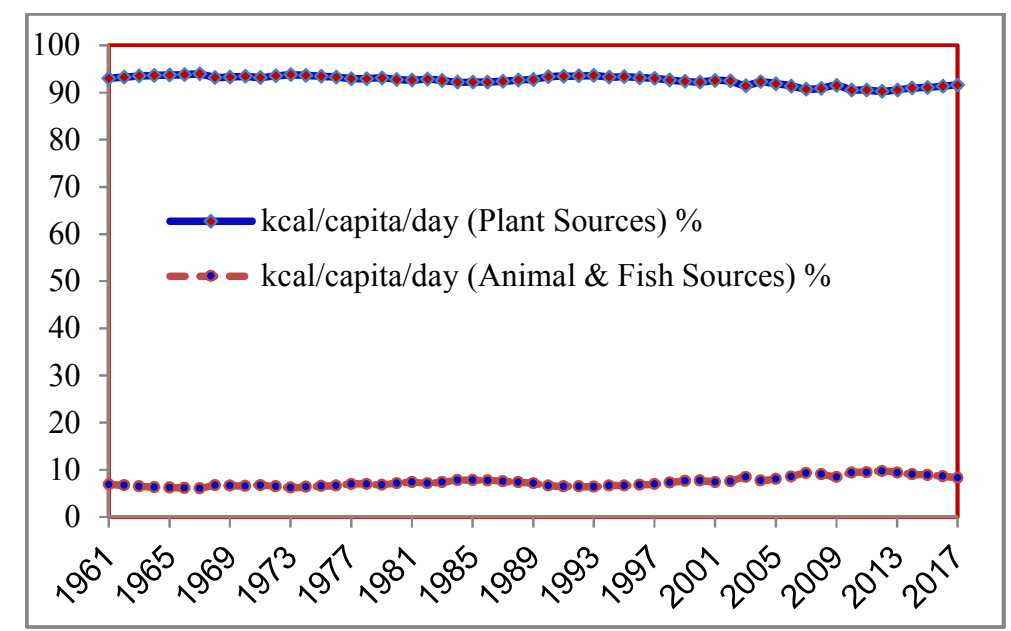

Fig. 2: Daily per-capita intake (Kcal/capita/day) according to its vegetable, animal and fish sources in Egypt during the period 2000-2017. 
Accordingly, it can be concluded that the Egyptian citizen depends on his food on the component of plant sources than his dependence on animal and fish sources, and that despite whoever gets more amounts of optimal energy, protein and fat needs, but most of it from plant sources and not from animal sources, due to the low per-capita income and the spread of poverty, which explains the spread of diseases especially poor nutrition anemia and stunting among children.

\section{A) Unit Root Test (ADF Test):}

Most of time series are non-stationary because they contain the unit root and the presence of the unit root in any time series results in average independence and variance from time to time. If a regression relationship is made in models of time series that actually contain the unit root, these results in a spurious regression, and problems in econometric analysis (Narayan and Smyth, 2008). Therefore, a test was conducted of the problem of the stability or stillness of the time series under study over time using the Unit Root Test. This test aims to examine the properties of the time series and ensure the extent of their stability and determine the order of integration of each variable (Order of Integration) separately, has been used Augmented Dickey-Fuller (ADF), which consists of estimating the following regression model:

$$
\Delta \mathrm{Y}_{\mathrm{t}}=\beta_{1}+\beta_{2} \mathrm{t}+\delta \mathrm{Y}_{\mathrm{t}-1}+\alpha \alpha \mathrm{i} \Delta \mathrm{y}_{\mathrm{t}-\mathrm{i}}+\varepsilon_{\mathrm{t}}
$$

Where $\varepsilon t$ represents the error term, where also:

$$
\Delta \mathrm{Y}_{\mathrm{t}-1}=\left(\mathrm{Y}_{\mathrm{t}-1}-\mathrm{Y}_{\mathrm{t}-2}\right) \quad \& \quad \Delta \mathrm{Y}_{\mathrm{t}-2}=\left(\mathrm{Y}_{\mathrm{t}-2}-\mathrm{Y}_{\mathrm{t}-3}\right) \text {, etc }
$$

The results of the unit root test showed that most of the time series in question are unstable at the Level, but they are stable at the first differences. (Table No. 2).

\begin{tabular}{|c|c|c|c|c|}
\hline & \multirow[b]{2}{*}{ Variables } & \multicolumn{2}{|c|}{ ADF Test } & \multirow[b]{2}{*}{ Result } \\
\hline & & Level & $1^{\text {st }}$ & \\
\hline $\mathbf{Y}$ & Calories per-capita daily intake (kcal/capita/day) & $-2.38^{\mathrm{ns}}$ & $-5.29^{* *}$ & $\mathrm{I}(1)$ \\
\hline $\mathbf{X}_{1}$ & Real Food Price Index & $1.66^{\mathrm{ns}}$ & $-7.90^{* *}$ & $\mathrm{I}(1)$ \\
\hline $\mathbf{X}_{\mathbf{2}}$ & Real GDP per-capita & $4.44^{\mathrm{ns}}$ & $-4.62^{* *}$ & I(1) \\
\hline $\mathbf{X}_{3}$ & Food Production Index & $1.27^{\mathrm{ns}}$ & $-7.43^{* *}$ & $\mathrm{I}(1)$ \\
\hline
\end{tabular}

Table 2: Results of the unit root test using the ADF test during the period 1961-2017

The multiple regression model was used in the double logarithmic form to estimate the relationship between the study variables, and the model illustrated in Table (3) was obtained, and the significance of the model as a whole is shown by the estimated F, and that the signs of the independent variables included in the model are logic, and they all explain about $81.8 \%$ of the changes in the calories per-capita daily intake in Egypt during the study period, the DW test indicate that there is no problem of Auto-correlation between the residual. It is clear that the three independent variables have a significant effect on the dependent variable, and that the real GDP variable per-capita $\left(\mathrm{X}_{2}\right)$ is the largest affecting the nutrition intake in Egypt (Y).

Table 3: Results of estimating the variables affecting calories per-capita daily intake in Egypt (1961-

\begin{tabular}{|c|c|c|c|}
\hline \multicolumn{4}{|c|}{ Dependent Variable: Calories per-capita daily intake (kcal/capita/day) (Y) } \\
\hline Method: Least Squares $\quad$ Sample: 1961-2017 & Included observatio & & \\
\hline Variable & Coefficient & t-Statistic & Prob. \\
\hline Intercept & 8.363 & 47.67 & 0.000 \\
\hline Real Food Price Index $\left(\operatorname{Ln} X_{1}\right)$ & -0.144 & -4.83 & 0.000 \\
\hline Real GDP per-capita (Ln X2) & 0.107 & 6.77 & 0.000 \\
\hline Food Production Index ( $\left.\operatorname{Ln} X_{3}\right)$ & 0.125 & 4.75 & 0.000 \\
\hline Adjusted R-squared & 0.818 & F-statistic & 28.35 \\
\hline Durbin-Watson stat & 2.040 & Prob. (F) & 0.000 \\
\hline
\end{tabular}
2017)

\section{B) Cointegration Test (Johansen Test):}

The Cointegration test was performed on the same set of variables using the Johansen test, the results in table (4) indicate that the null hypothesis that there is no Cointegration between the set of 
variables under study can be rejected (due to the existence of two directions for the Cointegration between these variables At probability level\% 1), either according to Trace Statistic or Max-Eigen Statistic. Consequently, it is not possible to reject the hypothesis that there is at least one vector for Cointegration between the set of variables under study, which indicates the existence of a static linear combination between these variables, and this result confirms the possibility of a long-term relationship between these variables, which means that these variables do not go away From each other in the long run.

Table 4: Results of Cointegration tests using the Johansen test of the variables affecting the calories per-capita daily intake in Egypt during the period 1961-2017

\begin{tabular}{|c|c|c|c|c|c|}
\hline Eigenvalue & Trace Static & $\begin{array}{l}5 \% \text { Critical } \\
\text { Value } \\
\end{array}$ & $\begin{array}{c}1 \% \text { Critical } \\
\text { Value } \\
\end{array}$ & $\mathbf{H}_{\mathbf{0}}$ & Result \\
\hline 0.687 & 102.539 & 47.21 & 54.46 & None $* *$ & Reject $\mathrm{H}_{\mathrm{O}}$ at $1 \%$ \\
\hline 0.402 & 38.561 & 29.68 & 35.65 & $\mathrm{r} \leq 1^{* *}$ & Reject $\mathrm{H}_{\mathrm{O}}$ at $1 \%$ \\
\hline 0.166 & 10.264 & 15.41 & 20.04 & $r \leq 2$ & Accept $\mathrm{H}_{\mathrm{O}}$ \\
\hline 0.004 & 0.247 & 3.76 & 6.65 & $r \leq 3$ & Accept $\mathrm{H}_{\mathrm{O}}$ \\
\hline
\end{tabular}

** Significant at 0.01

\section{C) Causality Relationship (Granger Test):}

The Granger Causality Test was used to confirm the existence of a Feed-Back relationship between two variables and to determine the direction of causality between them. The Granger-causality test is a suitable approach for finding out whether there exists any causal relation between two variables. This test aims to reveal the existence and direction of this relationship through Fisher's test of the null hypothesis that the first variable does not cause the second variable, and that the second variable does not cause the first variable at a certain level of significance, as opposed to the two alternative assumptions: the first variable causes the second variable, and the second variable causes the first variable, with a certain slowdown period. Table (5) shows a summary of the results using the Granger Causality Test to explore the direction of the causal relationship between nutrition, which is represented by the variable calories per-capita daily intake (Y), and the independent variables affecting it during the study period, using a delay period of one year. These results lead to a one-way causal relationship that extends from both the real food price index $\left(\mathrm{X}_{1}\right)$, the real GDP per-capita $\left(\mathrm{X}_{2}\right)$ to per-capita nutrition in Egypt, meaning that both food prices and economic growth cause nutrition intake during the study period at lagged period one year. While there is a two-way causal relationship between food production $\left(\mathrm{X}_{3}\right)$ and nutrition intake, that is, they cause each other, at one year lagged.

Table 5: Granger causality test results

\begin{tabular}{cccc}
\hline Sample: 1961 2017 & $\begin{array}{c}\text { Pairwise Granger Causality Tests } \\
\text { Lags: 1 }\end{array}$ & \\
\hline Null Hypothesis: & Obs. & F-Statistic & Probability \\
X1 does not Granger Cause Y & 56 & 4.304 & ns \\
Y does not Granger Cause X1 & & 0.596 & $*$ \\
X2 does not Granger Cause Y & 56 & 5.350 & ns \\
Y does not Granger Cause X2 & & 1.375 & $*$ \\
X3 does not Granger Cause Y & 56 & 3.924 & $*$ \\
Y does not Granger Cause X3 & & 3.867 & \\
\hline
\end{tabular}

\section{D) Variance Decomposition}

Table No. (6) illustrates the variance decomposition of the study variables during a 10-year period, in order to identify the relative importance of external shocks in explaining the fluctuations of the variables included in the model in the long term, and notes that the results of the analysis of the variance components are consistent with the results drawn from the results of the cointegration test, and reveals These results indicate that the portion of variance in the individual consumption of calories (Y) drops to about $16.75 \%$ during 10 years, which means that the independent variables explain or explain the shocks in consuming calories for 10 years, and it is clear that the recent changes in the real GDP per-capita $\left(\mathrm{X}_{2}\right)$ represent about $60.79 \%$ of calories shocks. The variation in the independent variables 
included in the model also indicates that real GDP per-capita is the main determinant of per-capita consumption of calories, which is consistent with the results previously reached.

Table 6: Analysis of the Variance Decomposition

\begin{tabular}{ccccc}
\hline Period & Y & X1 & X2 & X3 \\
\hline $\mathbf{1}$ & 100 & 0.00 & 0.00 & 0.00 \\
$\mathbf{2}$ & 97.54 & 0.18 & 1.49 & 0.79 \\
$\mathbf{3}$ & 83.20 & 3.14 & 11.05 & 2.61 \\
$\mathbf{4}$ & 74.21 & 5.13 & 18.02 & 2.64 \\
$\mathbf{5}$ & 65.45 & 6.12 & 23.86 & 4.57 \\
$\mathbf{6}$ & 57.62 & 7.22 & 28.62 & 6.54 \\
$\mathbf{7}$ & 51.74 & 8.12 & 32.66 & 7.48 \\
$\mathbf{8}$ & 42.85 & 9.11 & 37.61 & 10.43 \\
$\mathbf{9}$ & 27.22 & 10.11 & 51.64 & 11.03 \\
$\mathbf{1 0}$ & 16.75 & 11.09 & 60.79 & 11.37 \\
Cholesky Ordering: Y X1 X2 X3 & & & \\
\hline
\end{tabular}

\section{E) Impulse Response Function IRF}

The impulse response function is another way in which we can obtain information regarding the relationships between the variables included in the analysis of the components of variance to obtain an effect accompanying the change in each of them on the dependent variable, and can be relied upon in estimating the current and future reactions of a variable as a result of a temporary shock of Two standard deviations in another variable. It is also possible to study the causal relationship between the variables by tracing the impact of this shock. The impulse response function also allows for an assessment of the deviation of economic variables from the long-term equilibrium pathway. Figure (3) shows the pulse response functions that have been estimated among the variables under study, as it turns out that the three independent variables have a noticeable effect on the interpretation of the shock response in the calories intake, that is, they affect the changes in the dependent variable, and it is noted that the calories intake response to recent changes in per-capita GDP $\left(\mathrm{X}_{2}\right)$ are high, which means the Engel Law is achieved which indicates that at lower levels of income a greater proportion of income is spent on food.

Response to Cholesky One S.D. Innovations \pm 2 S.E.
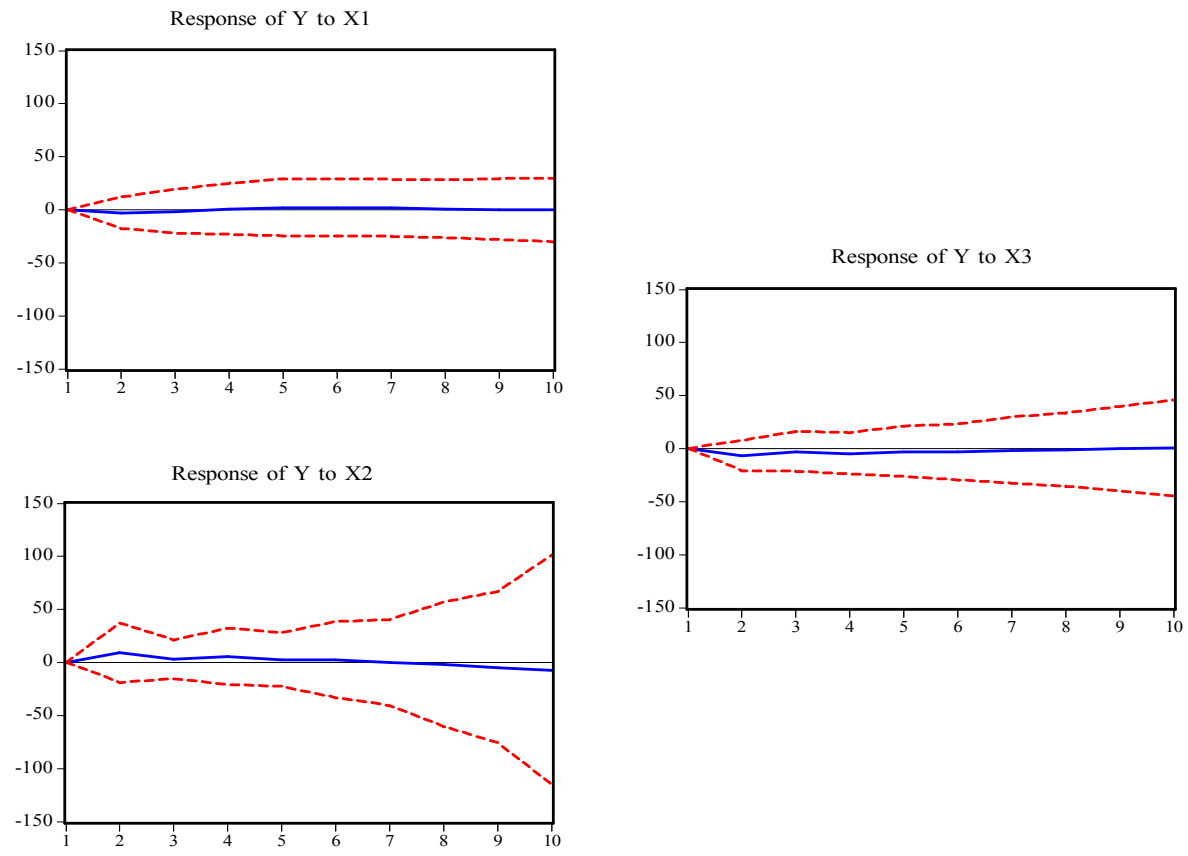

Fig. 4: The impulse response function 


\section{F) Model stability test:}

The stability of the model used was confirmed, as the Roots of Characteristic Polynomial test was applied, and the condition of model stability is that the estimated parameters (Modulus) less than the one, i.e. all the roots fall within the unit circle inside the Unit Cercle. It is clear from Table No. (7) and Figure No. (4) that the condition of stability of the model used in the study is fulfilled, which indicates the possibility of relying on the results of the estimated model as it is characterized by stable results.

\section{Roots of Characteristic Polynomial}

Variables: Y X1 X2 X3

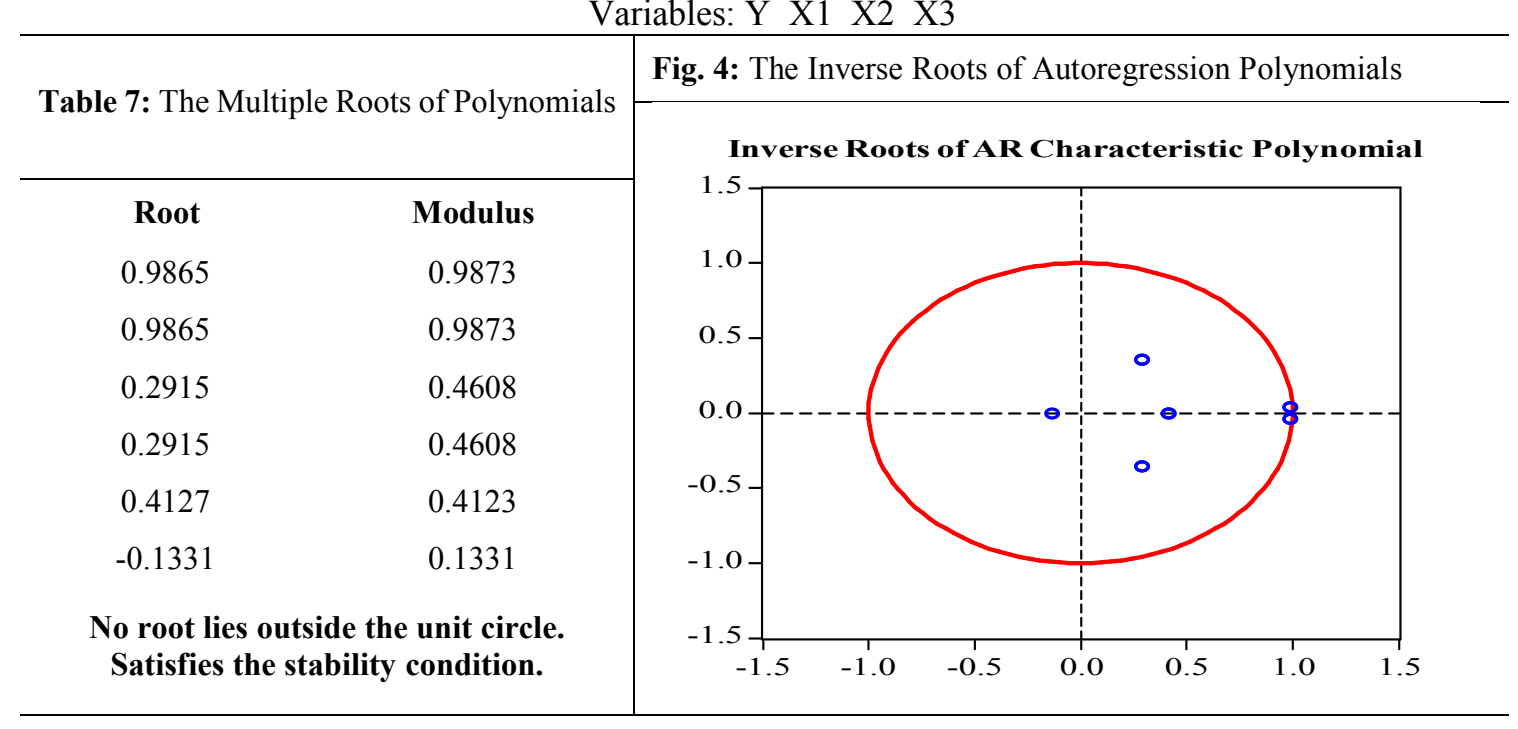

\section{Conclusion}

This study analyzed the long run causality relations across nutrition intake, economic growth, food prices and food production index in Egypt, by applying econometric analysis. The study demonstrates that there is Cointegration between the study variables, which confirm the possibility of a long run relationship, and is a statistically significant long-run relation between nutritional intake and economic growth. The real GDP per-capita is the main determinant of per-capita consumption of calories, and it is noted that the calories intake response to recent changes in per-capita GDP are high, which means the Engel Law is achieved which indicates that at lower levels of income a greater proportion of income is spent on food. It is important that efforts must be undertaken to encourage consumption of a wide variety of foods to improve the nutritional quality of the diet and health of the Egyptian population.

\section{References}

Enders, W., 1995. Applied Econometrics Time Series, Wiley, New York.

Engle, R. F. and C. W. J. Granger, 1987. Cointegration and Error Correction: Representation, Estimation and Testing, Econometrica 55, 251-76.

FAO, 1990-2018. Statistical Yearbook: World Food and Agriculture, Food and Agriculture Organization of the United Nations, Rome.

FAO, 2013. The State of Food Insecurity in the World 2013: The Multiple Dimensions of Food Security, FAO, Rome.

FAO, 2020. FAOSTAT Database, in FAOSTAT Database. Accessed: March 7, 2020.

Faridi, R. and S. N. Wadood, 2010. An Econometric Assessment of Household Food Security in Bangladesh, Bangladesh Development Studies, 33(3), 97.

Ferrière, N., and A. Suwa-Eisenmann, 2015. Does Food Aid Disrupt Local Food Market? Evidence from Rural Ethiopia, World Development, 76, 114-131.

Gujarati, D. N., 2004. Basic Econometrics, $4^{\text {th }}$ Edition, MaGraw-Hill New York. 
Manap, N. M. A. and N. W. Ismail, 2019. Food Security and Economic Growth, International Journal of Modern Trends in Social Sciences, 2(8), 108-118.

Matchaya, G. A. P., 2012. Estimating Effects of Constraints on Food Security in Malawi: Policy Lessons from Regressions Quantiles, Applied Econometrics and International Development, 12(2), 165-91.

Ministry of Agriculture and Land Reclamation, Economic Affairs Sector, Bulletin of Food Balance Sheet in the Arab Republic of Egypt, Cairo.

Narayan, P. K. and R. Smyth, 2008. Energy Consumption and Real GDP in G7 Countries: New Evidence from Panel Cointegration with Structural Breaks, Energy Economics, Elsevier, 30 (5): 2331-2341.

Nighat Hanif, N., M. Nisa, and M. R. Yaseen, 2019. Relationship between Food Security, Macroeconomic Variables and Environment: Evidences from Developing Countries, Journal of Applied Economics and Business Research JAEBR, 9(1): 27-37.

Phillips, P. C. and P. Perron, 1988. Testing for a Unit Root in Time Series Regression, Biometrika 75, 335-346.

Pourreza, A., S. Geravandi, and M. Pakdaman, 2018. Food Security and Economic Growth, Journal of Nutrition and Food Security, 3(3): 113-115.

Richards, C., U. Kjærnes, and J. Vik, 2016. Food Security in Welfare Capitalism: Comparing Social Entitlements to Food in Australia and Norway, Journal of Rural Studies, 43, 61-70.

Strauss, J. S., and T. Duncan, 1998. Health, Nutrition, and Economic Development, Journal of Economic Literature 36 (2): 766-817.

Timmer, C. P., 2004. Food Security and Economic Growth: An Asian Perspective, Center for Global Development, November.

World Bank, Commodity Price Data: Pink Sheet, Washington, DC: Development Prospects Group. Various Issues. Accessed: March 7, 2020.

http://blogs.worldbank.org/prospects/category/tags/historical-data. 